\title{
The Changing Conservation Scene
}

\section{Sarath Wimalabandara Kotagama}

Professor of Environment Science, Department of Zoology, University of Colombo

ABSTRACT
The science and practice of conservation of wildlife / biodiversity
has changed drastically over the years in the international arena due to
evolving social standards, scientific understanding of plants and animals,
ecology, and the impacts of human development. In Sri Lanka, these
changes have not taken root as yet, and thus the implementation of
conservation has been weak.
This article reviews the past and present status of global changes to
conservation as they affect the country, and outlines a future pathway to
achieving sustainable biodiversity conservation. Human lifestyle changed
from hunter -gatherer to the present via an initial agricultural -life style. The
changes resulted in major landscape and resource exploitation, ultimately
impacting the natural resources of the world. In this scenario, the desire
to conserve biological diversity emerged through attitudinal changes,
for example, from "Game" to "Wildlife" to "Biodiversity". Resolutions
for the conservation of biodiversity require an in-depth analysis of the
environment, followed by a clear recognition of this transition from Game
to Biodiversity.
The global interest in conserving biodiversity has been strengthened
by the Convention on Biological Diversity. Historical changes in Sri Lankan
legislation reflect the various stages of resource exploitation and response
to changes in global biodiversity. The new policy, while recognizing the
"sustainable use" of natural resources, falls short of enabling this to
happen. The future directions of conservation remain, therefore, a desire,
but possible through the recognition of weakness in existing legislature
and attitudes, and their subsequent rectification.

\section{KEYWORDS:}

Lifestyle, Environment, Game, Wildlife, Biological Diversity, Biodiversity, Conservation, Legislation.

Suggested Citation: Kotagama, S. W. (2021). The Changing Conservation Scene. University of Colombo Review (New Series III), 2(2), 05 - 31.

(C) 2021 The Authors. This work is licenced under a Creative Commons Attribution 4.0 International Licence which permits unrestricted use, distribution, and reproduction in any medium, provided the original work is properly cited. 


\section{Introduction}

The science and practice of conservation of wildlife / biodiversity has changed drastically over the years in the international arena due to evolving social standards, scientific understanding of plants and animals, ecology, and the impacts of human development. In Sri Lanka, these changes have not taken root as yet, and thus it appears that wildlife/ biodiversity conservation is being implemented like a boat at sea without a radar and sail. This article reviews the past and present status of global changes as they affect the country and seeks to outline a future pathway to achieve sustainable biodiversity conservation.

\section{Background}

The impact of humans on the natural environment can be traced to the onset of human evolution itself. As man evolved out of apes through the various hominid forms to become Homo sapiens, he was already progressing towards altering the environment or his surroundings. The change came primarily from his search for food, while taking shelter in natural caves or below ledges. He was thus able to escape the elements of nature - rain, high temperature, wind etc. The lifestyle referred to as "hunter-gather" required a very indepth understanding of the surroundings to enable the hunt and the gathering. The males performed the hunt while the females did the gathering. This life was full of uncertainties and thus insecure. In light of this situation, - even though he possessed the means for change, and a developed brain - man apparently remained a hunter-gatherer for $98 \%$ of the span of human existence on earth. The uncertainty prevented any future investments.

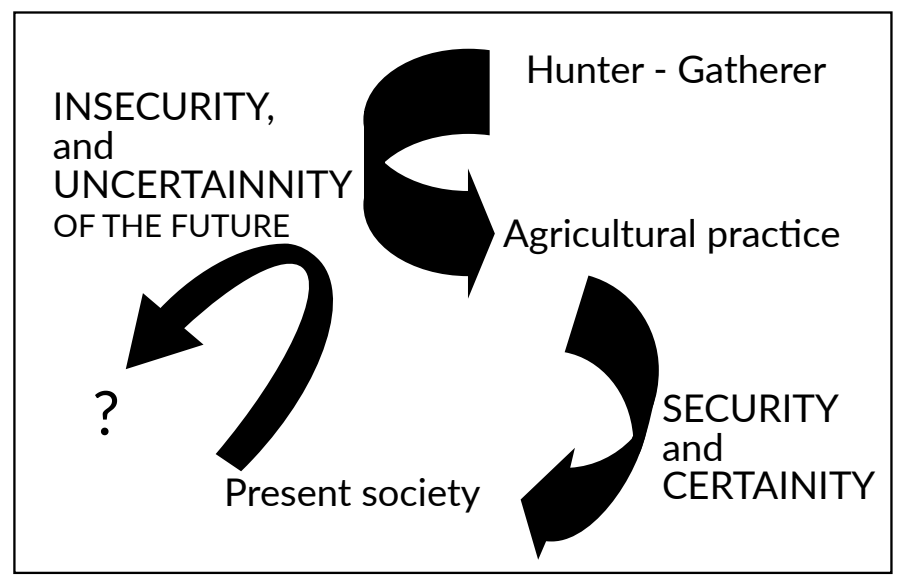

Figure 1

Historic Transformation of Society

Around 12,000-15,000 years ago, we are told, that man took the most remarkable step of manipulating his surrounding to engage in what we refer today as agriculture. This brought into life certainty and security, two of the most vital elements that enable investments for the future: creativity and innovations. Now, his lifestyle was set to make 
him the master of the system. His insecure and uncertain attitudes began to change. The manipulation and harnessing of nature became the main feature of human existence. Soon, man considered himself the ruler of nature. Nature was to be utilized for his benefit and manipulation. Man's abode was soon relocated from caves under rock ledges to flat lands close to fields. Human lifestyles rapidly changed: detached from the cave, man could now find himself shelter and safety in any place by building what was needed for that purpose. A new dimension was added to the environment - a built/structured environment. Soon this built/structured environment became the major location of all activities - settlements for living and fields for obtaining food.

This manipulative lifestyle is the main factor responsible for changing nature. While some natural areas were lost to the settlement and field. Ultimately the ideas of extinctions, threatened status and need for protection started to become necessary. The change in lifestyle also brought a third dimension to the present environment - theories that condition the human to be what he is. Based on education/learning, cultural ways and - since 1876 economics have fundamentally made us what we are today. We do not do anything today without considering the economic factor. Thus, the three elements of our environment the natural, built/structured, and theoretical elements - play the role of molding human lifestyles.

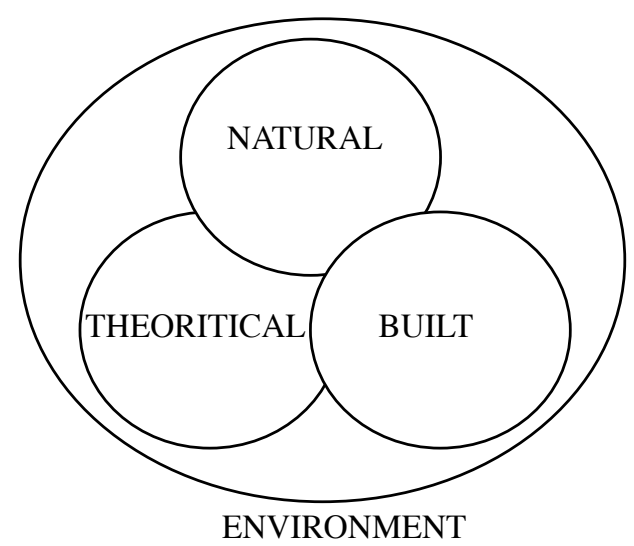

Figure 2

Components of the Environment

Certainty and security, along with the changing lifestyle, resulted in the increase of the human population. This triggered the need for more resources, cities, and technologies for living, and today, we are back to being insecure and uncertain about the future as a result of the impacts of this change. It must be noted that this insecurity and uncertainty stems from our own action which has resulted in what is now recognized as environmental problems. Among them are global climate change, loss of biological diversity and resulting extinction of species, poisoning of the earth, i.e., pollution, and impacts on human health through non-communicable health conditions to name a few. Even the present Covid-19, 
one of the $300+$ zoonotic diseases that we have been affected by in the last 70 years, could be considered an impact of interference with nature.

In the area of nature conservation, we note very clearly that the last 100 years have seen some dramatic changes in the understanding of wildlife and biological diversity, and the approach to conserve them. Among them, notable changes may be observed in:

- the shift in the use of terminology (e.g., from "game" to "wildlife" to "biodiversity")

- the resolution of the concepts of protection and conservation

- the recognition of sustainable use in biodiversity

- the emergence of the ecosystems approach in conservation

- the emergence of adaptive management in nature management

- the change from biological conservation to conservation biology

- the path towards regeneration and ecosystems restoration.

\section{From "Game" to "Wildlife" to "Biodiversity"}

Before Buddhism was embraced in Sri Lanka, it was most likely that hunting was enjoyed by the people (at least among the elite). This is indicated when Arahat Mahinda met King Devanampiyatissa while the latter was out hunting. After embracing Buddhism, however, this attitude changed. It is difficult to find incidents of hunting being carried out for pleasure or even as an accepted livelihood in available literature. Instead, it was considered a sinful act and hunters were negated as discards or lowly persons in society. They were not even permitted into places of worship and to social functions etc. Wildlife protection came under the patronage of the rulers, and through existing social norms, wildlife protection remained part and parcel of the lifestyle of the people.

Traditional philosophies enjoined man to respect, or even revere nature, and work in partnership with it. Forests were protected by Royal Edicts; tree felling and collecting of forest products were controlled; and the delicate and fragile ecosystem of the wet zone forest areas were left practically undisturbed. (Abeywickrama, 1986, p. 2)

Change in attitudes and land use practice commenced with the onset of the colonial period (1505-1948). Thus, over-exploitation and hunting for pleasure began. It is evident from the available literature that there was no doubt that Sri Lanka's central highlands and wet zone were forested prior to the European invasions of the country. The Dutch and Portuguese were interested in various types of trade, among which was the exporting of wild elephants (see Figure 3. Ferguson, 1901 as cited in Webb, 2002). When the British took control of the country, their initial attitude was to exploit natural resources optimally. 
Volume and Value of Elephant Exports, 1863-1899

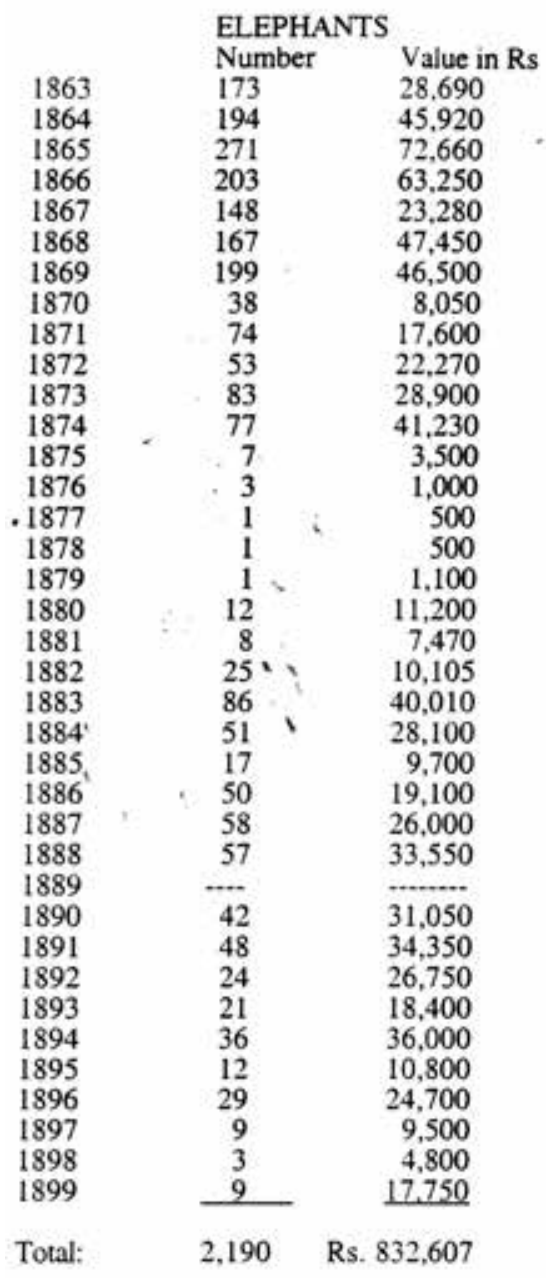

Source: J. Ferguson, Eerguson's Ceylon Handbook and Directory 1900-1 (Colombo, 1901), 651652.

\section{Figure 3}

Export of Elephants, 1863 - 1899

Note: Extracted from Ferguson (1901), as cited in Webb (2002).

These changes in attitudes towards animal p rotection and land-use which began with the onset of the colonial period had a significant influence on the country's legal system as well. Modern day legislation enacted to protect wildlife in the island can be traced back to the 1870s when the country was still under British colonial rule. This legislation was initiated upon recognition of the impacts of large-scale land alienation in the highlands of the country. 
Development of land had to continue, of course, and wildlife had to, just as inevitably, recede. The opening up of the highlands are well documented by Wickramagamage (2017). The process of deforestation in the hill country began only about 15 years after the conquest of the Kandyan Kingdom in 1815 by the British colonialists. But it did not take off in a big way until about 1840 which marked the beginning of the first wave of land alienation. (Wickramagamage, 2017, p. 24)

This acceleration was primarily due to the coffee plantations that expanded rapidly during the 1850s, 60s, and 70s, reaching a peak in 1878 (see Figure 4. from Webb, 2002).

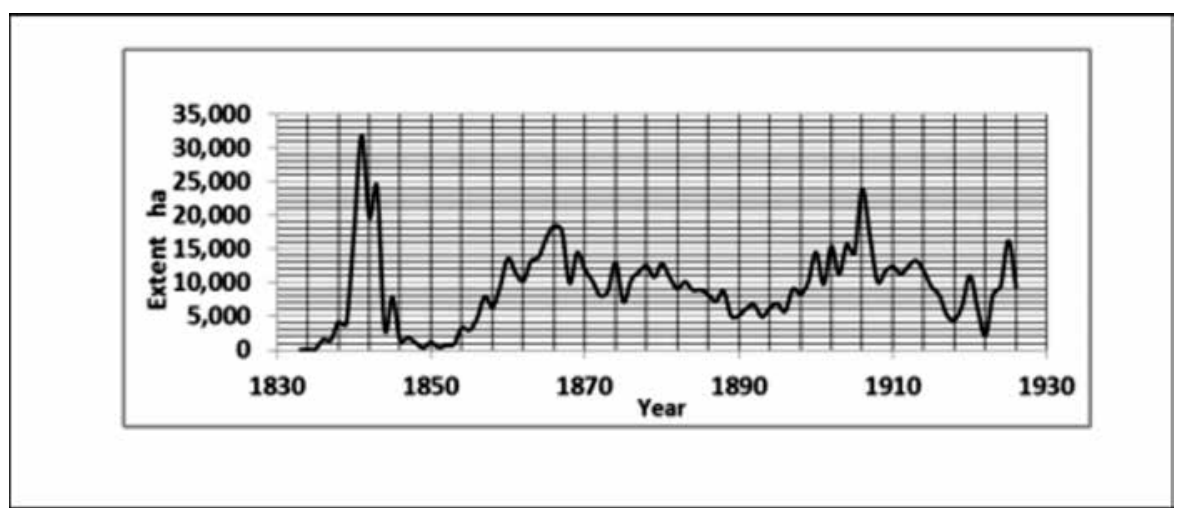

Figure 4

Extent of sale of crown lands in Ceylon during the British rule between 1833 and 1926

The rate of forest clearing for coffee came to an abrupt end with the spread of the coffee rust, Hemileia vastatrix, in 1868, but the extent of montane forest loss had its impact on the biodiversity.

The multitude of impacts that accrued from the clearing of highland forests can be classified as both direct and indirect. The direct impacts are the loss of biodiversity and habitats. The indirect impacts are degradation of soil through erosion and retardation of soil development, siltation of low-lying areas and riverbeds, and the increase in landslides and floods. The words of George Gardner, the Superintendent of the Royal Botanical Gardens, Peradeniya, succinctly describe the direct impacts of the clearing of forests for plantation agriculture as early as 1843 :

Of late large tracts of the country have been cleared of the virgin forests by which they covered, from the rapid spread of cultivation; and as this is likely to go on to a great extent there can be no doubt that many of those trees which are peculiar to the Island, and local in the range, will long become extinct; and the Botanists of future times will look in vain for many of those species which their predecessors had recorded in the annals of science as natives of the Island. This is no idle speculation; such having already occurred in other countries. (Gardner as cited in Webb, 2002)

The devastation caused to forest is quoted by Wickramagamage as cited in the Encyclopedia of Ceylon (1902) as follows: 
The summits of the highest ridges are clothed with verdure, and along their base, in the beautiful valleys which intersect them in every direction, the slopes were still within the last few years covered with forests of gigantic and valuable trees, which have now disappeared under the axe of the planter, who has felled and burnt the timber on all the finest slopes at an elevation of 2000 to 4500 feet, and converted the hillsides into highlycultivated coffee estates. (2017, p. 29)

The grave indirect effects of these practices are well documented by G. H. K. Thwaites, Director of the Royal Botanical Gardens, Peradeniya, and many commission reports on the subject. According to Bastianpillai (1968), Thwaites feared soil erosion, decreased rainfall, and eventual land desiccation unless the planters' activity was regulated. The forests in the highlands nourished the soil and protected it from erosion for thousands of years. Removal of this protective cover led to many onsite and offsite effects. The onsite effect was soil erosion and loss of soil productivity rendering sloping lands unproductive grasslands. Thwaites complained about the siltation of lowlands and riverbeds in the $1870 \mathrm{~s}$ at the height of the coffee industry. It is generally known that plantation land lost on average about $20 \mathrm{~cm}$ of its topsoil after the clearance of forests in the 19th Century. Thwaites managed to convince Sir Joseph Hooker, Director, Kew Gardens, of the seriousness of the situation in the colony. He cited examples of soil erosion in the uplands, and siltation of low-lying farmlands and riverbeds. These findings are corroborated by various Royal Commission reports produced in the late 19th and early 20th Centuries. Hooker's concern prompted the Colonial Secretary to issue an administrative order banning the clearing of government forest land above the $1524 \mathrm{~m}$ (5000 foot) contour. Even though this ban did not result in an immediate end to the clearing of forests in these areas, it had, at least, symbolic value in influencing the forestry policy of colonial rulers of the island. The Directors of the Royal Botanical Gardens, Peradeniya, who were concerned about the loss of endemic species from the highlands, in fact, attempted ex-situ conservation in botanical gardens in order to preserve these species for future generations (Wickramagamage, 2017)

\section{Evolution of Wildlife Legislation and Policy}

In the meantime, with the newly acquired weapon, the gun, men preyed on large animals in order to prove their superiority. Game hunting thereby emerged, targeting large animals. Along with game hunting and the illegal killing of animals, a change also occurred in attitudes towards these large animals. To mitigate this, an Ordinance to prevent wasteful destruction of buffaloes and game was introduced. In 1889, Colonel F. C. H. Clarke, the Acting Conservator of Forest, brought to the notice of the government the disastrous effects of commercial exploitation of wildlife, and his report paved the way for the introduction of an Ordinance to prevent wanton destruction of elephants, buffaloes, and other game in 1891. It provided for a closed season of five months during which killing of deer, sambur, buffalo, and peafowl was prohibited. Further, "game" was defined as sambur, spotted deer, red deer, barking deer, buffalo, and peafowl. Simultaneously, a law was also introduced for raising export duty on hides and horns. These legislations were introduced with the primary objective of safeguarding the interest of colonial hunters. In parallel, several 
more legislations were passed to mitigate the dried meat trade and to prohibit commercial exploitation of wildlife.

The passing of these ordinances immediately excited the public's interest, and two rival camps emerged: those adversely affected and those in favor of the new restrictions. The former immediately began a campaign against the restrictions while the latter formed the Game Protection Society in 1884 and played a pivotal role in the passage of future laws. The State continued to enact more protective legislations in the coming years.

For example, the Game Protection Act No 11 of 1902, the Fish (Dynamite) Act No 14 of 1905, Wild Bird Protection Act No 10 of 1906 and the Dried Meat Ordinance No 9 of 1908 (see Crusz, 1973, in Appendix A of this article) were passed to mitigate the commercial exploitation of wildlife and the dried meat trade. Although these early Ordinances were admittedly defective and sometimes inoperative, they could nonetheless be considered as the beginnings of modern-day wildlife conservation in Sri Lanka.

The Forest Ordinance No.10 of 1885 (FO), (Crusz, 1973, in Appendix A) enacted to regulate the uncontrolled destruction of forests was also the first legislation utilized to reserve areas for the protection of game animals. Two types of protected areas (PA) were declared under Section 19 of the FO: game sanctuaries (GS) where shooting of wildlife was strictly prohibited, and the Resident Sportsmen's Reserve (RSR), where shooting game animals was permitted under a license during the open season that usually lasted for about five months. The first GS was created on 20th March 1900 at Yala, and two more game sanctuaries were established in 1905 and were merged in 1909 to form the Wilpattu Game Sanctuary. Steps were taken to demarcate and reserve "surrounds" to each of these two sanctuaries as RSRs. These legal changes have been best summarized by Crusz (1973) (see Appendix A for an extract from this publication).

As the trade in dried meat was almost entirely dependent on the number of deer slaughtered at water holes during the closed season, an effort was made to put a stop to such illegal practices by means of employing watchers. This experiment proved a failure as it was soon discovered that most of these so-called watchers were subsidized by the poachers. At this juncture the Game Protection Society opted to abandon the process of employing watchers and decided to concentrate their staff in five selected localities, three of which abutted Yala.

Between 1909 and 1929, no outstanding difficulties or great progress with respect to conservation can be recorded. The period may best be described as one of consolidating existing regulations. One of the outstanding features of this period was the action taken to protect indigenous fauna which involved:

- putting a stop to all forms of commercial exploitation;

- prohibiting the practice of slaughtering animals over water holes;

- prosecuting persons who hunted with aid of electric torches at night; and

- concentrating on intensive protection of specified areas.

The years that followed showed a marked change in conditions. Communications improved, more areas of the country were opened up, and cultivation expanded, reducing the forest cover and thus curtailing the area available for occupation by wildlife. 
The Game Protection Society is, today, the Wildlife and Nature Protection Society. This change in moniker signals a clear shift from its original mission and has had much to do with the attitudinal change from seeing animals as game to wildlife. The means to protect game animals from illegal hunters and loss of habitat resulting from development was to set aside lands for the animals. The lands or protected areas have thus become the backbone of modern-day conservation. Accordingly, "wildlife" referred to large animals (game) within protected areas. Animals outside the PA system were not considered as requiring protection or conservation.

\section{Legislation on the Fauna and Flora of Ceylon}

The end of the First World War resulted in importing shot guns in large numbers. By the mid-1920s, it became clear that the existing law for protecting game animals needed to be further amended. The government placed the administration of the forests and all that they contained under the Ministry of Agriculture and Lands. Under the Ministry's new policy of re-allotment of crown land for specific uses, the important requirement of allotting specified areas for the intensive protection of the island's fauna received consideration and attention. One of the first measures taken was to appoint a Select Committee in 1926 to examine the fauna and flora. Sessional Paper XXXIII of 1930 was the outcome of the long deliberation, which recommended the declaration of extra sanctuaries and the restriction of gun licenses as well trade and export of animals and animal parts (Government of Ceylon, 1930; Nicholas, 1952). The Committee also proposed the introduction of an entirely new Ordinance titled "An Ordinance for the Protection of Fauna and Flora of Ceylon". The term "game" was taken out from the title of this new Ordinance, as it provided wider coverage, including the protection of flora, rather than emphasizing the preservation of wild animals for the purpose of sport. The Fauna and Flora Protection Ordinance No 2 of 1937 (FFPO) came into force on 1st March 1938. It provided provisions for the establishment of protected areas (PAs) where all fauna and flora within the specified areas would be free from detrimental human interference, and for the listing of species that would enjoy protection throughout the country.

Within the Sri Lankan context traditionally, wildlife meant the larger game animals, such as elephants, bear, deer, leopard etc. The new Fauna and Flora Protection Ordinance of 1937 did not even have a definition for wildlife in the country. The definition for "fauna" was derived from the classification of "wild animals" as "any animal which is not a domestic animal". The definition for "domestic animal" was provided as "any head of cattle, or any sheep, goat, horse, ass, mule, dog or cat; any domestic fowl or other bird commonly reared by man as poultry; and when domesticated by man, any elephant, buffalo, pig, deer, hare, rabbit, peacock, parrot, pigeon or other animal". This leads us to the definition of an animal as "any vertebrate or invertebrate animal and includes a bird, fish or reptile". This strange definition appears to indicate that fish, birds, and reptiles are not vertebrates, while amphibians are not included (FFPO, 1937, Chapter 469, Section 11, Interpretation of Part 1, pp. 8-9). 
The definition of the flora component appeared as "plants" and was described as "any member of the vegetable kingdom and includes the seed or any other part of any plant" (FFPO No 2, 1937). Today this definition would be considered strange for two reasons: firstly, because it refers to an undefined concept of a "vegetable kingdom"; and secondly, because the term "vegetable" refers only to those plants that are used for food by man, and not to plants that are inedible.

Although these were not the most accurate definitions for wildlife, they surprisingly remained unchallenged till 1989. The change to have a holistic, more scientifically accepted definition of wildlife was introduced through the proposed wildlife policy document in 1989 (Kotagama, 1989). In 1990, the Government of Sri Lanka adopted the first comprehensive wildlife policy, and in it the definition for wildlife was "plants and animals which owe their existence to natural phenomenon or to processes that occur autonomously" (DWC, 1990). Accordingly, this definition was incorporated into the 1994 amendment to the FFPO (No 49, 1993). The subsequent amendment in 2009 (FFPO No 22, 2009) continues to use the above definition for wildlife. The definition thus includes all living organisms and in today's context becomes synonymous with "biological diversity" or "biodiversity".

\section{Establishment of the Department of Wildlife}

In 1937, a new consolidated act, the Fauna and Flora Protection Act, was approved along with numerous categories of PAs and protection to some plants and fauna. The emphasis in this legislation was very clear as given in Section 1. "The ordinance may be cited as the fauna and flora protection ordinance" (FFPO No 2, 1937). The administration of the recognized PAs under the FFPO was under the Forest Department. Very soon it came to be realized that the Forest Department's role was questionable. This was because the Forest Act enabled the harvesting and exploitation of the forest while the FFPO was to protect the forest from any extractive exploitation. Soon this dilemma of a contradictory approach to common forest resources resulted in a dialogue that ended with the establishment of two separate Departments governed by the Forest Ordinance and the FFPO.

The 1949 Forest Department (FD) Administration report spells out the policy of the new Wildlife Department as follows:

Since October 1949 a Wild Life Department has been formed by the Ministry of Agriculture and Lands as it has become increasingly apparent that the perpetuation of the indigenous fauna is essential to the country's welfare. Endowed by nature with a wild fauna rich in variety, beauty and interest, it has become the duty of the present generation to hand it down to posterity in as complete a form as possible. The new department's function will be to implement this policy. (Forest Department Administration Report, 1949, section 89).

The new Department continued to be under the Conservator of Forests until 1st October 1950, when Mr. C. W. Nicholas was appointed as the Wildlife Warden.

Subsequently, a Select Committee was appointed in 1957, to look into and recommend directions to the wildlife sector. The deliberations were presented as Sessional Paper XIX 
in the Report of the Committee on Preservation of Wildlife (Government of Ceylon, 1959). This document had some very far-reaching recommendations that are valid even for today. The futuristic thoughts presented there were not implemented possibly because the general attitude was still preservationist. Let me quote some sections to illustrate this.

On Sinharaja, it noted that: "[t]he inaccessible upper area of this forest which are unsuitable for forest exploitation should be declared a Strict Nature Reserve" (Government of Ceylon, 1959, p. xi). On conservation of wildlife-related education and research, it noted:

The Education Department, in consultation with the Department of Wildlife, should prepare and allocate suitable syllabuses in regard to the preservation of wildlife, to be included in the Teacher's Training Courses in the Training Colleges and the Schools.

Undergraduates of the Universities studying Botany and Zoology should be encouraged to make excursions into our jungles and National Reserves with the advice and help of the Department of Wildlife and study the subjects in a practical manner.

The Parks should be published in schools and Universities to encourage students to undertake research.

The Department of Wildlife Conservation must devote more time to applied Biology and establish a research unit to study the problems of all types of wildlife.

WLD Rangers and WLD Guards should be trained...

Special classes in Biology should be arranged...

Staff officers and the present Assistant Wardens should be sent for courses in Wildlife Management...

It was only 29 years later that the recommendations presented in this paper would begin to take partial form under the Wildlife Department. Today, the Department has a fully-fledged National Wildlife Training Facility although its performance is questionable.

\section{Biological Diversity and New Legislation to the Forefront}

Changes to the conservation and protection of nature under the theme of biodiversity came about in the 1980s. In 1981, the World Conservation Congress (IUCN) General Assembly discussed the need to ensure the "sharing of benefits arising out of the exploitation of the Biological Diversity" (IUCN, 1983). This intervention ended with the UN Convention on the Conservation of Biological Diversity. With this, the emphasis started shifting from "protection" to "conservation" and included the involvement of people or people participation.

The original term "biological diversity" was coined by Thomas Lovejoy. This was shortened and the new word "biodiversity" was coined by W. G. Rosen in 1985 while planning the 1986 National Forum on Biological Diversity, organized by the National Academy of Sciences, USA (NFB, 1986). Through the actions of O. E. Wilson, a renowned entomologist, the word "biodiversity" became popular, and the use of the term "wildlife" slowly receded. However, the appearance of the word "biodiversity" in the scientific 
literature came about only in 1998 (Kaennel, 1998). The word "biodiversity" set the stage for a new chapter in the protection, conservation, and sustainable use of nature.

Biodiversity, an acronym for biological diversity, is thus referred to as a "pseudo cognate" or a coined word. The meaning has never been directly defined but is interpreted as per the definition of biological diversity given in Article 2 of the Convention on Biological Diversity (CBD) that was approved in 1992 (CBD, 1993). The CBD recognizes biodiversity at three levels - genetic diversity, species diversity, and ecosystems diversity. The Convention was also heavily influenced by the environmental movement of the time. Stepping away from "protection" to "sustainable use", the United Nations Commission on Sustainable Development provided its ideological nucleus. Soon " "biodiversity" became the key word at all forums and "wildlife" was replaced.

"Biodiversity" differs from "wildlife" in that it refers to all organisms in all locations, and sustainable utilization. It moves away from the total emphasis on protection and the limitations on protected areas. The subjects broaden and the efforts become very involved and confusing. The efforts lean towards conservation rather than protection. This requires some change to legislation built around the concept of protection.

In 1990, Sri Lanka saw the inclusion of these philosophical changes into the wildlife sector through the government approved "Wildlife Conservation Policy of 1990" (DWC, 1992). The policy contained very forward-looking aspects (see Appendix B). It would not be wrong to state that there was considerable opposition, and non-acceptance of the content of the Policy by the wildlife enthusiast of the time. Even today, many are yet to comprehend these changes. These changes came about even before the approval of the CBD in 1992. This was because insight on the CBD document was available to the author (Kotagama 1989), and the Policy would have enabled Sri Lanka to become a pioneer in biodiversity conservation. Sadly however, it remained a document with little implementation, primarily because of the difference in wildlife protection and biodiversity conservation.

The Sri Lanka Wildlife legislation of 1970 was amended in 1993 with consideration to the aforementioned policy. This amendment brought in some ideas of sustainable use, and new principles of conservation, but they were far from meeting the CBD objectives. For instance, the preamble of this legislation stated that it was:

[a]n ordinance to provide for the protection, conservation and preservation of the fauna and flora of Sri Lanka; for the prevention of the commercial exploitation of such fauna and flora; and to provide for matters connected therewith or incidental thereto (FFPO, 1993, Preamble),

which was clearly not in line with the CBD objectives which are as follows:

- Objective 1 - the conservation of the biological diversity;

- Objective 2 - sustainable use of its components; and

- Objective 3 - the fair and equitable sharing of the benefits arising out of the utilization of genetic resources. (CBD, 1993, Article 1) 
The Sri Lankan legislation on wildlife does recognize some of the different uses of flora and fauna even though it does not define commercial purpose. It recognizes protection, conservation, and preservation as three different activities that meet one objective. Despite this, the absence of recognition of "biodiversity" by the conservation fraternity of the time meant that progress was slow.

In 2000, the National Wildlife Policy for Sri Lanka of 1990 was revised (see Appendix C), incorporating further ideas of sustainable use, and people participation etc. Even though it did not come close to the ideas presented in the CBD, the global focus on conservation and biodiversity was emphasized. This was a commendable step. Some efforts to incorporate the ideals of conservation were affected with the outreach programs and the reluctant acceptance of ecotourism in a limited way by the Wildlife Conservation Department. Keeping in line with this new revision of the Wildlife Policy, the FFPO was amended in 2009 (No. 22, 2009).

In the meantime, the establishment of the Biodiversity Secretariat in the Ministry of Environment as well as the development of the Biodiversity Action Plan for the country took place in 1994. The establishment of the Biodiversity Secretariat brings a third element of state machinery onto the conservation stage (Wildlife and Forestry being the other two). Its role is to be the focal point for the $\mathrm{CBD}$ and co-ordinate activities related to biodiversity in the country.

As time passed, the significance of biodiversity became dominant and prominent. The Forest Department changed its name to become the Department of Forest Conservation. Its activities duplicated the role of the Wildlife Department. Even more interestingly, the Department of Forest Conservation rode the waves of biodiversity so well that the wet zone and hill country forest assets became more important than the traditional PAs that are mostly in the Dry Zone and under the purview of the Wildlife Department. The Forest Ordinance was amended to incorporate "Conservation Forests" in the revised Forest Act of 2009 (Forest Act No. 65, 2009). These Conservation Forests were similar to that of the Strict Nature Reserves (SNRs) in the FFPO. These Conservation Forests that are around 40+ in number are, in terms of biodiversity, much richer than the reserve network of wildlife, as many are in the wet and montane zones of Sri Lanka.

In 1936, it was recommended that the Sinharaja Forest Reserve, declared as such in 1876, should be declared as an SNR, but this was not carried out due to the value of timber. However, when it was proposed that the remaining Sinharaja Forest Reserve be logged for plywood in 1969, public outcry resulted in the abandonment of this project and the saving of the forest reserve. This was followed by intense faunal and floral research by the University of Peradeniya and a march for conservation carried out by the University of Colombo which resulted in the Sinharaja Forest (of what was left) being protected under a new legislation - the Wilderness Heritage Act (1989) - and subsequently receiving World Heritage status (Sinharaja Forest Reserve, 1988). This Act was put together to ensure that the "crown of the forest" in terms of biodiversity remained with the forest sector despite the practical aspect of "non-exploitatory protection" provided by the Wildlife sector at the time. Starting from here and followed by the National Conservation Review in 1990 which 
involved the survey of all forests over 200ha for its biodiversity, the Forest Department's stakes in biodiversity increased. Today with eco-tourism, education centers and even "elephant watching" promoted by the Forest Department, its role is a clear duplication of the mandate of the Wildlife Department.

Biodiversity, while uniting divided natural resources (forest and related fauna) and bringing institutes functionally closer, has also opened avenues to other traditional and indigenous knowledge-based disciplines. Among these are Ayurveda, the use of medicinal plants, and multiple uses of biological material in trade etc. The aspect of "use" which was one of the thorns in wildlife protection has become a major area of attention in biodiversity conservation. It therefore cannot be neglected. It also opens up the areas to economic reasoning - an aspect that was shunned by traditional wildlife conservationists. It is these fundamental changes that make protection a more closed paradigm and conservation an open, more socially acceptable one. As such, biodiversity has become a concern for all persons despite their interest in the value of nature and its protection. The United Nations theme for 2010, "Biodiversity is our life" aptly recognized this. In passing it may be said that Sri Lanka attempted to introduce this idea for wildlife in 1990 when the Department of Wildlife proposed the theme "To Promote the Acceptance of Wildlife" and the general public adopted the theme "Wildlife is our Life". For those who have followed wildlife interests in the country, the consequent arousal of the general public, especially in the Sinhala vernacular, is evidence of this move. In Sinhala, we changed "อъぇљรอ" (wanasathwa) to "อே๕อ" (wanajeewi) and the theme to "Wanajeevin ape jeevayayi" (Wildlife is our Life) which became an instant "hit" and evoked deep feelings in people for our biological diversity.

Biodiversity touches every person's heart or soul. It has multiple attributes. This makes it important to both the committed naturalist and to the commercial exploiter. To bring the two extremes together to achieve conservation is the challenge of the day. The term "wildlife" did not achieve this, and the Sinhala term showcases that effectively, as the pre-1990 translation of "wildlife" in Sinhala was "wanasaththu", literally meaning wild animals. This was changed to "wanajeewi" (อљஃð, i.e., wildlife) in 1990.

Similarly, biodiversity has woken the world to the diverse aspects of nature, and its conservation viz., "the management of human use of the biosphere so that it may yield the greatest sustainable benefit to present generations while maintaining its potential to meet the needs and aspirations of future generations." (World Conservation Strategy, 1980, pt. 4). This was the impetus for the definition of sustainable development espoused by the Brundlandt Commission of 1987, later adopted by the Rio Conference 1992, and the foundation of all actions to the present with respect to sustainable development.

In the future one must be conscious of and take into account all the elements of biodiversity conservation, the shift from biological conservation to conservation biology, the ecosystems approach, the landscape ecological approach, and adaptive management. The emergence of ecosystem services, and economic aspects such as valuation and its significance have further socialized the concepts of conservation. These are present day disciplines/approaches that the knowledge economy and society have to understand in order to achieve the ultimate goal of nature conservation for the future. 


\section{Conclusion and the Way Forward}

Since the adoption of the first comprehensive Wildlife Policy in 1990, which was principally to direct the development of the Protected Area system, the Policy underwent revisions in 2000 to further broaden its mandate to include wider efforts at the conservation of biodiversity and achieving sustainable development of the nation.

Taking into consideration Sri Lanka's present effort to offer high standards of livelihood to its people, a 10-year Wildlife Resources Conservation proposal was developed based on the vision of "Wildlife is the Lifeline of the Nation" (DWC, 2015). The value of biodiversity through its multiple uses in the modern world requires the outlook on wildlife to go beyond the past. The CBD to which Sri Lanka is a signatory provides the opportunity to maximize the benefits of wildlife resources. Taking into consideration the growing demand for numerous bio-products and the principles of bio-financing, a new wildlife resources approach is necessary. Five thrust areas are proposed as the way forward as indicated below:

- mainstreaming wildlife resource conservation (WRC) for sustainable development of the nation through integrating WRC objectives and practices with other development sectors; promoting benefit sharing for community development through participatory approaches; resolving WRC conflicts (e.g., human-elephant conflict); and responding to climate change (CC) (e.g., carbon assessments for the "Reduce Emissions from deforestation and forest degradation in developing countries" (REDD+) ) through adaptation and mitigation in response to $\mathrm{CC}$ impacts.

- effecting the "Lifeline for Sustainable Development" by enabling bioprospecting through legislation and development of a structural framework for development; linking biodiversity through the "value chain"; increasing income generation from PA systems; and promoting sustainable use of ex-situ biodiversity

- building the capacity of the Department of Wildlife Conservation (DWC) for adaptive management through marking boundaries and consolidating PAs; harnessing information technology for effective management; upgrading the National Research and Training Center at Giritale to an international level; re-assessing the DWC's institutional structure to meet field-based ecosystems conservation; establishing and implementing a biodiversity database; and enhancing field staff benefits for better output.

- looking beyond land-based conservation to the marine system through survey and declaration of appropriate marine/ocean reserves for conservation; purchasing equipment for patrolling and effecting conservation actions in the ocean; training and capacity building of staff and equipping them with appropriate equipment; and developing new marine based research, education, and training facilities.

- meeting regional and global obligations through strengthening the DWC to meet these obligations.

Thus, these activities need to be incorporated in the above thrust areas where required, along with building an international division in the DWC. The most pressing conventions that require attention are Convention on International Trade in Endangered Species of Wild 
Fauna and Flora (CITES), Convention on the Conservation of Migratory Species of Wild Animals (CMS), CBD, and Ramsar.

The future of sustainable biodiversity conservation in Sri Lanka lies, therefore, in the proper understanding of the objectives of the CBD and aligning the FFPO objectives with it as presented in the Policy of 2000. Despite the 2009 revisions of the FFPO falling far short of the objectives of "conservation", the FFPO still remains the principal legislation to protect our biodiversity today.

\section{References}

Abeywickrama, B. A. (1986). The threatened plants of Sri Lanka. UNESCO and MAB national committee for Sri Lanka, Publication No. 16. NARESA.

Bastianpillai, B. E. S. J. (1968). The Administration of Sir William Gregory, Governor of Ceylon 1872-77. Tisara Prakasakayo.

Clarke, F. C. H. (1890). Report of the Conservator of Forests for 1889. Forest Conservancy. Part IVMiscellaneous Ceylon Administration Report for the Year 1889. George J.A Skeen, Government printer.

Convention concerning the protection of the world cultural and natural heritage; UNESCO; Adopted, 16 November 1972

Convention on Biological Diversity, December 29, 1993.

Coomaraswamy, V. (1939a). Administration Report of the Conservator of Forests for 1937. Part II-Revenue (G).

Coomaraswamy, V. (1939b). Administration Report of the Conservator of Forests for 1938. Part II-Revenue $(G)$.

Coombe, G. (1942). Ceylon's reserves, national parks and sanctuaries. LORIS: The Journal of Ceylon Wildlife, 11(6).

Crusz, H. (1973). Nature conservation in Sri Lanka (Ceylon). Biological Conservation, 5(3).

de Silva, J. A. (1951). Administration Report of the Conservator of Forests for 1949. Part II- Revenue $(G)$.

de Alwis, L. (1982). River basin development and protected areas in Sri Lanka. In, J. A. McNeely \& K. R. Miller (Eds.), National parks, conservation, and development: The role of protected areas in sustaining society (Proceedings of the World Congress on National parks, Bali, Indonesia, 11-22 October 1982). Smithsonian Institution Press.

Department of Wildlife Conservation. (1990). A national policy for wildlife conservation in Sri Lanka. Ministry of Lands, Irrigation and Mahaweli Development.

Department of Wildlife Conservation. (1992). A national policy for wildlife conservation of Sri Lanka. Government of Sri Lanka. 
Department of Wildlife Conservation. (2004). A guide to national parks of Sri Lanka (2nd ed.).

Department of Wildlife Conservation. (2013). Performance report-2012.

http://www.parliament.lk/uploads/documents/paperspresented/performance_report_department of_wildlife_conservation_2012.pdf

Department of Wildlife Conservation. (2015). 10 year wildlife resources conservation plan.

Government of Sri Lanka.

Encyclopedia of Ceylon. (1902). https://www.1902encyclopedia.com/C/CEY/ceylon.html

Fauna and Flora Protection Ordinance No. 2. (1937). Government of Sri Lanka.

Fauna and Flora Protection Ordinance. (1970). Government of Sri Lanka.

Fauna and Flora Protection Ordinance No. 49. (1993). Government of Sri Lanka.

Fauna and Flora Protection Ordinance No. 22. (2009). Government of Sri Lanka.

Fernando, M. P. S. (1987). Some forestation programme in Sri Lanka: A historical perspective. In K. Vivekanandan (Ed.), 1887-1987: 100 years of forest conservation. Forest Department, Ministry of Lands and Land Development.

Fernando, R. (1990). New organizational structure for management of wildlife resources by the Department of Wildlife Conservation.

Forest Department. (1949). Forest Department administration report.

Forest (Amendment) Act No. 65, Supplement to Part II of the Gazette of the Democratic Socialist Republic of Sri Lanka. (2009).

From the Administration Report of the Acting Warden Department of Wildlife for 1968-69. (1971). LORIS: The Journal of Wildlife Protection Society of Ceylon, 12(3), 140-147.

Government of Ceylon. (1934). Sessional Paper XIX - 1934. Report of the Fauna and Flora Protection Committee, October 1934.

Government of Ceylon. (1930). Sessional Papers XXXIII - 1930. Report of the Select Committee on the Game Protection Ordinance.

Government of Ceylon. (1959). Sessional Paper XIX - 1959. Report of the Committee on Preservation of Wildlife.

Hoffmann. T. W. (1971). The Fauna and Flora Protection Ordinance (as amended by Act No.1 of 1970). LORIS: The Journal of Wildlife Protection Society of Ceylon, 12(3), pp 169-70.

International Union for Conservation of Nature. (1983). Proceedings of the IUCN General Assembly 1981, Christchurch, New Zealand.

Kaennel, M. (1998). Biodiversity: a diversity in definition. In P. Bachmann, M. Köhl, \& R. Päivinen (Eds), Assessment of biodiversity for improved forest planning (pp. 71-81). 
Kotagama, S. W. (1989). Towards a national policy for wildlife conservation. Bio News, 5(1-2).

Lushington H. E. C. (1935). Administration report of the Acting Conservator of Forest for 1934. Part II-Revenue $(G)$.

Lushington H. E. C. (1948). Administration report of the Acting Conservator of Forests for 1946. Part II- Revenue (G).

Lushington, H. E. C. (1949). Extracts from the administrative report of the Conservator of Forest for 1948. LORIS: The Journal of Ceylon Wildlife published by the Ceylon Game and Fauna Protection Society, 5(2), 172-173.

MAL \& F. (1995). Sri Lanka Forestry Sector Master Plan. Forestry Planning Unit, Ministry of Agriculture, Land and Forestry, Sri Lanka

Ministry of Environment and Natural Resources. (2006). Portfolio of strategic conservation sites / protected area gap analysis in Sri Lanka. EML Consultants for the Ministry of Environment and Natural Resources.

Ministry of Forestry and Environment. (1997). Designing an optimum protected areas system for Sri Lanka's natural forests, Volume 1. Environmental Management in Forestry Development Project.

Nanayakkara, V. R. (1987). Forest history of Sri Lanka. In K. Vivekanandan (Ed), 1887-1987: 100 Years of Forest Conservation. Forest Department, Ministry of Lands and Land Development.

National Forum on Biodiversity, September 21 - 24, 1986, Accession 92-030.

Nicholas, C. W. (1952). Administration report of the Warden, Department of Wildlife for 1951. Part IV-Education, Science and Art (N). Government Press.

Nicholas, C. W. (1955). Administration report of the Warden, Department of Wildlife for 1954. Part IV-Education, Science and Art (N). Government Press.

Norris, C. E. (1954a). National trust the only hope for Ceylon's reserves. LORIS: The Journal of the Wildlife and Nature Protection Society of Ceylon, 6(6), 239-240.

Norris, C. E. (1954b). Alienation of land from Wilpattu National Reserve. LORIS: The Journal of the Wildlife and Nature Protection Society of Ceylon, 6(6), 241-248.

Pabla, H. S., \& Mathur, V. B. (2001). Planning for conservation of biological diversity: Lessons learnt from Sri Lanka. LORIS: The Journal of the Wildlife and Nature Protection Society of Ceylon, 22(5), 30-36.

Panwar, H. S. (1994). Human resource development and institutional strengthening of the Department of Wildlife Conservation of Sri Lanka: A review of requirements (Inception Report, UNO/ SRL/001/GEF). Department of Wildlife Conservation, Sri Lanka.

Parkeer, A. S. A. (1974). Gleanings from the Acting Director's administration report 1969-70. LORIS: The Journal of the Wildlife and Nature Protection Society of Ceylon, 13(4). 
Report of the Committee for the Formulation of a National Policy for the Preservation of Fauna and Flora. (1985).

Saparamadu, S. (2006). Sri Lanka - A wildlife interlude, Volumes I and II. Tissara Prakasakayo.

Sinharaja Forest Reserve. (1988). UNESCO, World Heritage Convention, Date of Inscription: 1988; Criteria: (ix)(x).

Storey, H. (1921). A Ceylon sportsman's diary: An account of the author's shooting experiences from 1909 to 1920 inclusive with numerous illustrations. Times of Ceylon.

Strong, T. A. (1940). Administration report of the Conservator of Forests for 1939. Part II- Revenue $(G)$.

Strong, T. A. (1942). Administration report of the Conservator of Forests for 1941. Part II- Revenue $(G)$.

Uragoda, C. (1994). Wildlife conservation in Sri Lanka: A history of Wildlife and Nature Protection Society of Sri Lanka, 1894-1994. Wildlife and Nature Protection Society of Sri Lanka.

Webb, J. L. A., Jr. (2002). Tropical pioneers: Human agency and ecological change in the highlands of Sri Lanka, 1800-1900. Ohio University Press.

World Conservation Strategy. (1980). Introduction, pt 4. IUCN, UNEP, \& WWF.

Wickramagamage, P. (2017). Role of human agency in the transformation of the biogeography of Sri Lanka. Ceylon Journal of Science, 46(5), 19-31. http://doi.org/10.4038/cjs.v46i5.7452

Wikramanayake, E. B. (1954). Game protection and the law. LORIS: The Journal of the Wildlife and Nature Protection Society of Ceylon, 6(6), 231-234.

Wildlife Department - Extracts from the Warden's Administration Report 1951. (1952). LORIS: The Journal of Ceylon Wildlife, 6(2), 66-69. 


\section{Appendix A}

Legislative History of Sri Lanka (Ceylon then) from Crusz, Hilary (1973)

202

\section{TABLE I}

Stmmary of Main Conservation Sieps Taken in Sri Lanka (formerly Ceylon)

\begin{tabular}{|c|c|c|c|}
\hline $\begin{array}{l}\text { Government sessional papers, } \\
\text { ordinances, acts, and } \\
\text { proclamations }\end{array}$ & Tiste andior objects & $\begin{array}{l}\text { Other significant events for } \\
\text { nature conservation }\end{array}$ & Outlook \\
\hline Ordinance No. 10 of 1885 & The Forest Ordinance & $\begin{array}{l}\text { Governmen: Department } \\
\text { of Forestry established in } \\
1887 \text {, which administered } \\
\text { wildlife affairs up to } 1950\end{array}$ & $\begin{array}{l}\text { From } 1885 \text { to } 1929 \text {, the main } \\
\text { outlook of bolh Government } \\
\text { and the Game Protection } \\
\text { Society was 'conservation for } \\
\text { sport' }\end{array}$ \\
\hline
\end{tabular}

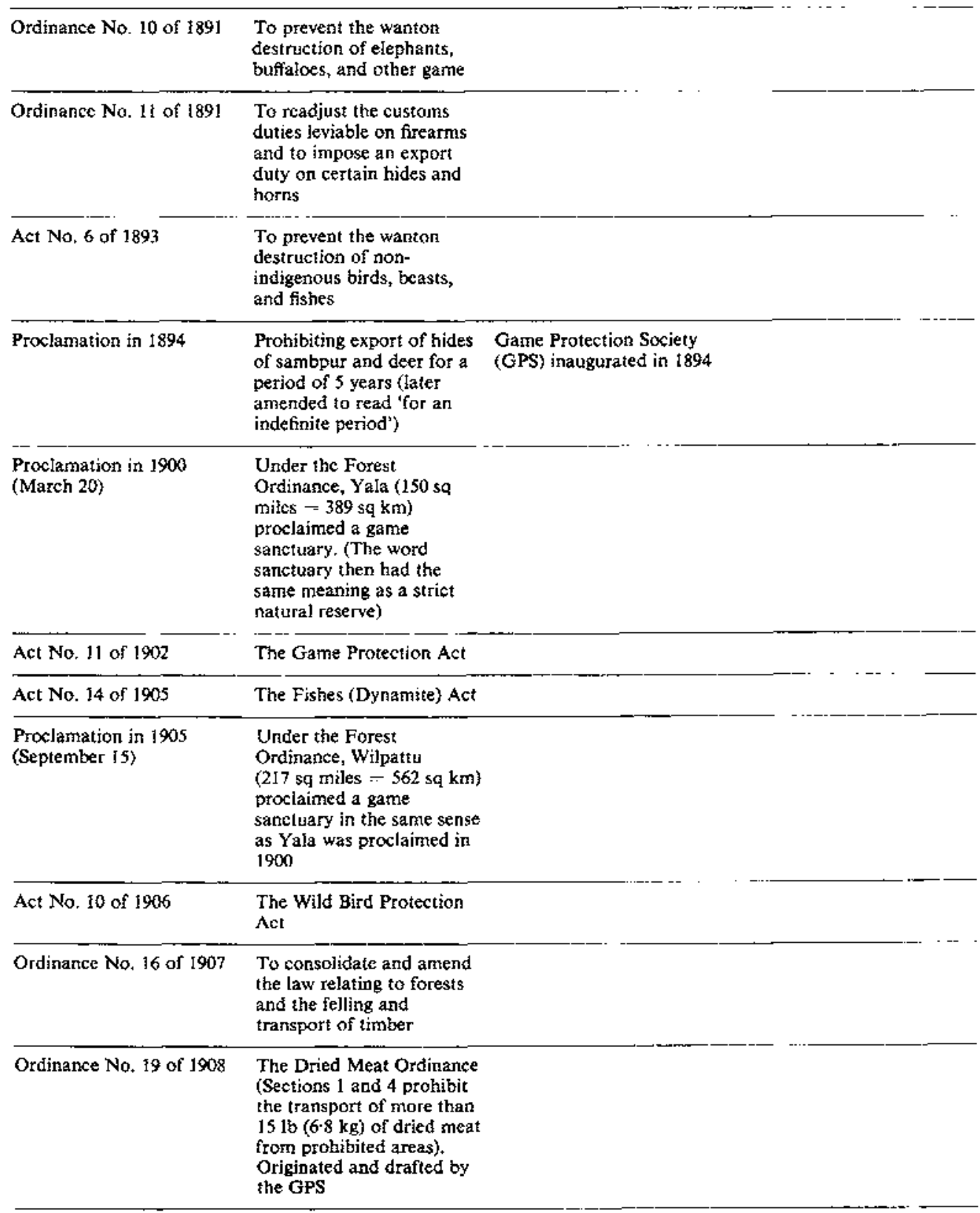


TABLE I-contd.

\begin{tabular}{|c|c|c|c|}
\hline $\begin{array}{l}\text { Goternment sessional papers, } \\
\text { ordinantes, acts, and } \\
\text { proclamations }\end{array}$ & Title andior object.5 & $\begin{array}{c}\text { Other significam events for } \\
\text { narture conservation }\end{array}$ & Outlook \\
\hline Ordinance No, 31 of 1908 & $\begin{array}{l}\text { Amendinent to the } \\
\text { Firearms Ordinance. } \\
\text { Originated and drafted by } \\
\text { the GPS }\end{array}$ & & \\
\hline Ordinance No. $i$ of 1909 & $\begin{array}{l}\text { For the protection of game, } \\
\text { wild beasts, birds, and fish. } \\
\text { 'Consolidation of all } \\
\text { existing laws relating to } \\
\text { wildlife protection.) } \\
\text { Originated and drafted by } \\
\text { the GPS }\end{array}$ & $-\cdot$ & $\cdots$ \\
\hline $\begin{array}{l}\text { Sessional Paper XXXllI of } \\
1930\end{array}$ & $\begin{array}{l}\text { Report of the Sclect } \\
\text { Committee on the Game } \\
\text { Proteclion Ordinance } \\
\text { (Chairman Mr W. E. Wait), } \\
\text { to consider and report on } \\
\text { the working of the } \\
\text { restrictions imposed by or } \\
\text { under the Game Protection } \\
\text { Ordinanee, and to make } \\
\text { any recommendations they } \\
\text { may consider expedient for } \\
\text { the alteration of such } \\
\text { restrictions }\end{array}$ & $\begin{array}{l}\text { Ceylon's new Constitution } \\
\text {-the Donoughmore } \\
\text { Constitution-came into } \\
\text { operation in } 1930 \text {. Nature } \\
\text { Conservation came under } \\
\text { the Ministry of Agriculture } \\
\text { and Lands. In the same } \\
\text { year the GPS was renamed } \\
\text { the Game and Fauna } \\
\text { Protection Sociely (GFPS), } \\
\text { which urged that protection } \\
\text { be given to all indigenous } \\
\text { orchids }\end{array}$ & $\begin{array}{l}\text { From 1930, a new outlook } \\
\text { inspired Government } \\
\text { enactments and the } \\
\text { Society's activities: nature } \\
\text { conservation, animal } \\
\text { photography, and scientific } \\
\text { studies, gained more } \\
\text { emphasis than sport }\end{array}$ \\
\hline $\begin{array}{l}\text { Sessional Paper XIX of } \\
1934\end{array}$ & $\begin{array}{l}\text { Report of the Fauna and } \\
\text { Flora Protection } \\
\text { Committee, appointed by } \\
\text { the Minister of Agriculture } \\
\text { and Lands, "to inquire into } \\
\text { and report on the measures } \\
\text { necessary to be taken for } \\
\text { the further protection of } \\
\text { the indigenous fauna and } \\
\text { Rora of Ceylon" } \\
\text {. ... - }\end{array}$ & $\begin{array}{l}\text { The Zoological Gardens at } \\
\text { Dehiwala taken over by } \\
\text { Government in 1935 on } \\
\text { representations made by } \\
\text { the GFPS. The Society also } \\
\text { drew attention to the } \\
\text { serious nature of the } \\
\text { dynamiting of fish }\end{array}$ & \\
\hline Ordinance No. 2 of 1937 & $\begin{array}{l}\text { The Fauna and Flora } \\
\text { Protection Ordinance }\end{array}$ & $\begin{array}{l}\text { The Faund and Flord } \\
\text { Protection Advisory } \\
\text { Committee appointed for } \\
\text { the first time in } 1938 \text {, } \\
\text { under Section } 70 \text { of the } \\
\text { Ordinance }\end{array}$ & \\
\hline Ordinance No. 24 of 1940 & $\begin{array}{l}\text { The Fisheries Ordinance, to } \\
\text { amend and consolidate the } \\
\text { law relating to fisheries and } \\
\text { to the taking and protection } \\
\text { of fish in Ceylon waters, } \\
\text { etc. (Amendments in 1950, } \\
\text { I952, and 1956) }\end{array}$ & & \\
\hline Ordinance No. 31 of 1942 & $\begin{array}{l}\text { Amendment to Fauna and } \\
\text { Flora Protection Ordinance }\end{array}$ & & \\
\hline Ordinance No. 12 of 1944 & $\begin{array}{l}\text { Amendment to Fauna and } \\
\text { Flora Protection Ordinance }\end{array}$ & & \\
\hline
\end{tabular}


TABLE I-contd.

\begin{tabular}{ll}
\hline $\begin{array}{l}\text { Government sessional papers, } \\
\text { ordinances, acts, and } \\
\text { prociamations }\end{array}$ & Title andlor objects \\
\hline Act No. 38 of 1949 & $\begin{array}{l}\text { Amendment to Fauna and } \\
\text { Flora Protection Ordinance }\end{array}$ \\
\hline Act No. 25 of 1951 & $\begin{array}{l}\text { The Soil Conservation Act. } \\
\text { (This has become almost a } \\
\text { dead letter, as there has } \\
\text { apparently not been a singie } \\
\text { prosecution yet under this } \\
\text { Act-see Hofimann, 1968) }\end{array}$ \\
\hline
\end{tabular}

Sessional Paper No. XIX of 1959
Other significant events for nature conservation

\section{Outbok:}

Independence Day,

4 February 1948. The

Government Department of

Wild Life was created in

1950, for which the GFPS

had agitated since 1928

\section{I,ife. (One of its \\ recommendations is to establish a National Trust or Corporation for the adrinistration of wildife in Ceyion. The President of the WLPSC has suggested that this Trust administer not onily wildlife but all Nature Conservation)}

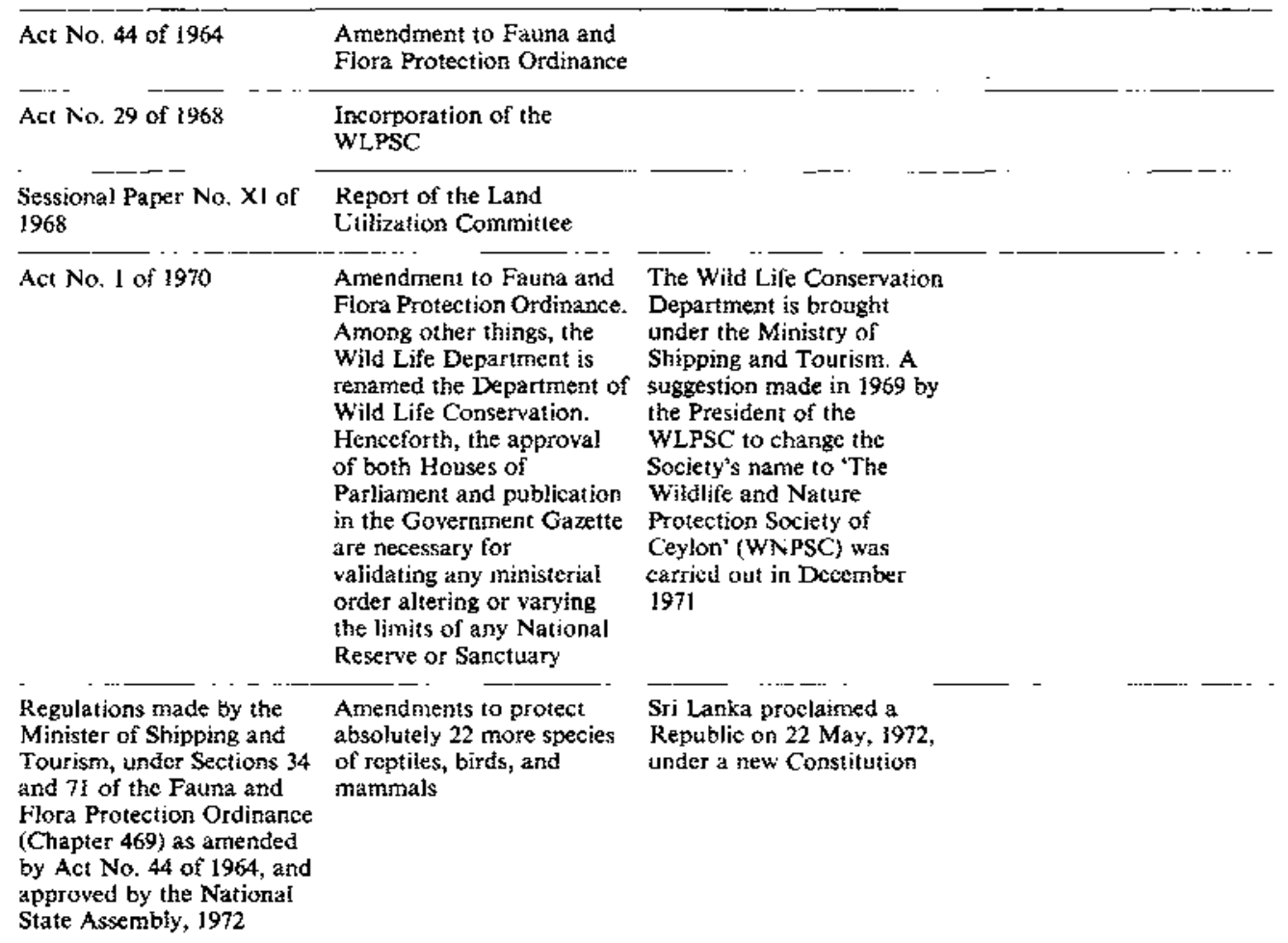




\section{Appendix B}

The National Policy for Wildlife Conservation 1990

The Cabinet approved Wildlife Policy has TWO parts. The first part is the general Policy for the entire sector. The SECOND part contain specific Policy directions for the Management of Protected Areas which is the main instrument of wildlife conservation.

\section{PART ONE}

AN OVERALL POLICY FOR WILDLDIFE (BIODIVERSITY ) CONSERVATION IN SRI LANKA, has the following three objectives:-

- TO MAINTAIN ECOLOGICAL PROCESSES AND LIFE-SUSTAINING SYSTEMS

- TO PRESERVE GENETIC DIVERSITY, ESPECIALLY THE BIODIVERSITY AND ENDEMIC BIOTA

- TO ENSURE SUSTAINABLE UTILIZATION OF THE WILDLIFE RESOURCE

\section{PART TWO}

This section contain SPECIFIC POLICIES TO ACHIEVE WILDLIFE CONSERVATION THROUGH THE MAIN INSTRUMENT OF CONSERVATION-THE ESTABLISHMENT AND MANAGEMENT OF PROTECTED AREAS

1. IDENTIFY THE SPECIFIC OBJECTIVES OF WILDLIFE CONSERVATION. Through the Formulation of a MANIFESTO OF VARIED OBJECTIVES which would suite each AREA DECLARED FOR PROTECTION.

2. DEMARCATE PROTECTED AREAS IN THE WET ZONE TO PRESERVE THE ENDEMISM AND BIODIVERSITY OF THE WET ZONE AS AN URGENT MEASURE.

3. RE-ASSESS OBJECTIVES FOR PROTECTED AREAS, TO RE-ASSESS ALL EXISTING PROTECTED AREAS, AND NEW AREAS IDENTIFIED FOR PROTECTION, SCIENTIFICALLY AND EXAMINE WAYS AND MEANS OF MEETING THE OBJECTIVES OF THESE AREAS, THEIR ECOLOGICAL STABILITY AND THE NEEDS OF THE PEOPLE.

4. RECOGNIZE HUMAN - USE IN PROTECTED AREAS, TO IDENTIFY POTENTIAL HUMAN USES OF PROTECTED AREA WHICH ARE COMPATIBLE WITH THE OBJECTIVES OF THE AREA, REGULATE AND CONTROL THEIR ACTIVITIES ON A SUSTAINABLE BASIS.

5. RECOGNIZE MULTILPE - USE IN PROTECTED AREAS, TO PERMIT MULTIPLE USE OF PROTECTED AREAS, IN ACCORDANCE OF ITS SUSTAINABILITY WITHOUT AFFECTING THE ECOLOGICAL STABILITY OF THE AREA. 
6. ESTABLISH ZONES IN PROTECTED AREAS, TO DEMARCATE ZONES OF ACTIVITY TO ACHIEVE THE SPECIFIC OBJECTIVES OF THE PROTECTED AREA. ALONG WITH OTHER SUSTAINABLE USES

7. INTRODUCE AN EFFECTIVE POLICY OF MANAGEMENT, TO ACCEPT AND INTRODUCE THE CONCEPT OF SCIENTIFIC MANAGEMENT FOR PROTECTED AREAS TO ENSURE ECOLOGICQAL STABILITY AND SUSTAINABILITY.

8. DECENTRALIZATION OF ADMINISTRATION, TO ESTABLISH LOCAL ADMINISTRATION TO MAKE POSSIBLE THE DISBURSEMENT OF BENEFITSFROMPROTECTED AREAS TO PEOPLE LIVING IN THE IMMEDIATE VICINITY OF THE AREAS.

9. RECOGNOTION OF RESEARCH AND EDUCATION AS PRIORITY NEEDS, TO RECOGNIZE THE IMPORTANCE OF RESEARCH AND EDUCATION IN THE EFFORTS OF CONSERVATION AND TO PROMOTE THE SAME.

10.ESTABLISH INTER-INSTITUTIONAL LINKS, TO BRING ABOUT A CLOSE LINK BETWEEN INSTITUTES CONCERNED IN PROMOTING CONSERVATION AND ALSO BETWEEN INSTITUTES CONCERNED WITH DEVELOPMENT, TO ENSURE A MORE PRACTICAL IMPLEMENTATION OF NATURAL RESOURCE CONSERVATION.

11. RECOGNISE THE IMPORTANCE OF EX-SITU CONSERVATION, TO RECOGNISE AND PROMOTE THE CONCEPT OF EX-SITU CONSERVATION.

12.CREATE A NATIONAL CONSERVATION LAW, TO FORMULATE AND IMPLEMENT A NATIONAL CONSERVATION LEGISLATION INCORPORATING THE FOREGOING GUIDELINES AND ALSO THE FUNDAMENTAL CONCEPT OF CONSERVATION AS PRACTISED TODAY. 


\section{Appendix C}

National Wildlife Policy for Sri Lanka-2000

(Approved by the cabinet of ministers (Cabinet Paper 00/1034/34/019).)

\section{Overview}

The first National Policy on Wildlife Conservation was approved by cabinet in June 1990 . The present National Wildlife Policy addresses many of the same issues in updated form, while also adding some points that respond to the evolving needs of Sri Lankan society and the additional mandates of the Convention on Biological Diversity (CBD), which Sri Lanka ratified in 1994.

It is the intention of Government to define a strategy to implement this policy as soon as possible through a Biodiversity Conservation Action Plan, supported by such legislative measures as may be necessary to achieve harmony and success among all those who seek to promote conservation and sustainable development in Sri Lanka.

\section{Objectives of the National Wildlife Policy}

The Objectives of this National Policy are:

To conserve wildlife resources, through protection, research, education, sustainable use and benefit sharing, for the benefit of present and future generation.

To maintain ecological processes and life-sustaining systems, with particular regard to primary production, hydrological balance, nutrient cycles, and prevention of erosion, siltation, drought and flood.

To manage all components of genetic diversity, as resources to improve crop plant and farm animal, and to develop in a fair and equitable manner new product and processes through bio-prospecting.

To ensure sustainable use and equitable sharing of benefits, arising from the direct and indirect use of wildlife resources and ecosystems.

To conserve native and endemic species and their habitats, so as to maintain the overall species richness and ecological integrity of the country.

To encourage the development of biological repositories, for the purposes of conservation education and science.

To encourage the private sector and communities to join as a full partners in all aspects of the wildlife-conservation process. 


\section{Policy on Protected Area Management and wildlife Conservation}

National Policy in this area is:

To develop national strategies, plans and programmes for wildlife conservation, in line with appropriate national and international standards.

To protect viable and representative samples of all ecosystems, including sites of special scientific interest, and wherever necessary to enlarge and connect protected areas to create viable conservation units.

To take urgent steps to conserve all remaining natural wet zone forests, which are underrepresented in the national systems of protected areas.

To identify, classify manage and monitor all protected areas, on the basis of appropriate scientific studies and agreed criteria.

To manage all protected areas according to approved management plans, which will be reviewed and revised regularly, and implemented by staff at the field level who will be afforded such authority and resources as they need to do so effectively.

To ensure that protected areas are internally zoned according to accepted criteria, to reflect the different resources within each zone and the most appropriate sustainable use of resources.

To manage all protected areas the context of their surrounding landscapes, taking into account the ecological, social and economics links between natural and human systems.

To promote active, ecosystem-based management of all protected areas, including the eradication wherever possible of alien and invasive species, subject to though consideration of the environmental impacts of these interventions.

To regulate the importation of alien organisms, including genetically-modified organisms, so as to minimize risks to the integrity of Sri Lanka's biodiversity.

To prepare and implement species recovery plant for all endangered species, using objective criteria for their identification developed by a national task force or other expert consultative mechanism.

To encourage and enable the sustainable the development of communities living around protected areas, by ensuring that local people are consulted in the process of decision making, actively participate in implementation, and receive direct benefits from the management of protected areas.

To facilitate eco-tourism in protected areas, to the extent that it provides benefits to local people and does not damage the ecosystem concerned. 


\section{Policy on institutional Support for Wildlife Conservation}

National policy in this area is:

To provide adequate support to wildlife resource managers, and to reorient, strengthen and decentralize their institutions as necessary to enable them to accomplish their task effectively.

To amend or revise legislation as necessary to support the implementation of this policy.

To promote research and education as valuable contributors to the national effort on wildlife conservation.

To value the traditional knowledge of sustainable ecosystem use possessed by the people of Sri Lanka, and incorporate this as appropriate within wildlife-management systems.

To encourage ex-situ conservation measures, where they can be shown to contribute to wildlife conservation, environmental education and the scientific understanding of how to use biodiversity sustainably.

\section{Policy on Inter-sectoral linkages}

National Policy in this area is:

To monitor events and take action needed to maintain consistency between the national wildlife policy and other sectoral and inter-sectoral policies.

To promote co-operation among stakeholders through participatory decision making at all levels. 